\title{
Establishment of Axenic Explants and Callus Induction of Vernonia amygdalina Del.
}

\author{
YEE YAN EVELINE KONG* \& HAMSAWI SANI \\ Department of Plant Science and Environmental Ecology, Faculty of Resource Science and Technology, \\ Universiti Malaysia Sarawak, 94300 Kota Samarahan, Sarawak, Malaysia \\ *Corresponding author: evelinekong@gmail.com
}

\begin{abstract}
Vernonia amygdalina is a plant with great medicinal potentials due to the phytochemicals it possesses. The establishment of axenic culture and callus induction are important as the primary steps to acquire callus and cell suspension cultures which are prospective to be used as alternatives in the production of phytochemicals. The effect of different regimes of sterilization unveiled that explants treated with mercuric chloride showed significant difference in the mean number of axenic explants, but observations of serious necrosis in all explants that later lead to death were recorded. Whilst, the explants treated with Clorox ${ }^{\circledR}$ were not significantly difference in the mean number of axenic explants but the explants obtained were healthy and the growth was sustained. For callus induction, there was no significant difference in the callus induction frequency (CIF) among different concentrations of 2,4-D or picloram. In conclusions, the explants were recommended to be surface sterilized with $15 \%$ of $\mathrm{Clorox}^{\circledR}$ for 15 minutes as it was more economical and less time consuming. Whereas, MS media supplemented with $0.5 \mathrm{mg} / \mathrm{L} 2,4-\mathrm{D}$ or $0.5 \mathrm{mg} / \mathrm{L}$ picloram would be a better choice for callus induction due to observation of root formation at lower concentrations of 2,4-D.
\end{abstract}

Keywords: Vernonia amygdalina, axenic, callus induction, surface sterilization, plant growth regulator, phytochemical

\section{INTRODUCTION}

Bitter leaf or scientifically known as Vernonia amygdalina Del. is a small tree or shrub that belongs to the family Asteraceae (Fomum, 2004; Ofori et al., 2013). Vernonia genus has a total of 109 species being reported to have medicinal properties. The most commonly used species is V. amygdalina (Toyang \& Verpoorte, 2013). The leaf of $V$. amygdalina has been used as traditional medicine to treat fever, malaria, dysentery, hepatitis, diarrhea as well as cough. Also, the leaves are used to treat headache, stomachache, scabies, malaria and gastrointestinal disorders (Fomum, 2004). Secondary metabolites or phytochemicals possess in $V$. amygdalina are the one that is responsible for pharmacologic activities such as hypoglycaemic, hypolipidemic, antimalarial, antioxidant and anti-inflammatory activities (Audu et al., 2012). The major bioactive compounds of $V$. amygdalina are sesquiterpene lactones and stigmastane-type steroid glucoside compounds (Yeap et al., 2010).

However, bitter leaf with great medicinal potentials is grown for personal needs rather than for commercial purposes. The processed leaves of $V$. amygdalina are sold at high price as compared to raw commodity in Cameroon. Conventional propagation of $V$. amygdalina is commonly by rooting of stem cuttings where mature stems are selected while seeds are also used (Fomum, 2004). Propagation is plausible by using seeds collected from dry flower heads but stem cuttings are used in general due to faster growth (Ofori et al., 2013). In spite of conventional propagation, studies shown that in vitro micropropagation played a key role in clonal propagation of elite genotypes of $V$. amygdalina for the production of secondary metabolites that are valuable by pharmaceutical means (Khalafalla et al., 2007).

Plant cell culture is promising potential alternative sources to produce secondary metabolites at commercial scale (Rao \& Ravishankar, 2002). There are reports on the production of phytochemicals in both suspension and callus cultures. Some secondary metabolites are produced in higher concentrations in cultured cells as compared to the whole plants of the same species (Linden, 2002). On top of that, plant cell culture makes great strides for the production of pharmaceuticals and chemicals as the synthesis 
of bioactive compounds through cell cultures are independent from soil and climate conditions (Ramakrishna \& Ravishankar, 2011). In addition, a well-established culture system can provide more stable content of bioactive compounds as compared to harvesting plants from different areas. Eventually, quality control will be facilitated and maximum production of target compounds can be regulated (Hu \& Jia, 2012). Therefore, this study was designed to obtain axenic cultures of $V$. amygdalina and induce callus from in vitro leaf as the primary steps for further experiments in cell suspension culture. The production of callus from suspension culture will be a source of bioactive compounds that is supposed to be stable and can be manipulated.

\section{MATERIALS AND METHODS}

\section{Plant Materials}

Stems of $V$. amygdalina plants were collected from the green house of Universiti Malaysia Sarawak and propagated by stem cuttings. New shoots develop from axillary buds were collected and nodal segments were used as explants for surface sterilization.

\section{Surface Sterilization}

To begin with, the shoots were cut into pieces of nodal segments and washed thoroughly under running tap water for 25 minutes. Two steps surface sterilization method with prior treatment of $70 \%(\mathrm{v} / \mathrm{v})$ ethanol for one minute was used. The explants were disinfected by using various concentrations of mercuric chloride, $\mathrm{HgCl}_{2}(0.1,0.2$, and $0.5 \%)$ for different durations (1, 3, and 6 mins). After immersion with sterilizing agents, the explants were rinsed thrice with sterile distilled water and the damaged ends were trimmed off. The explants were excised into approximately 1.0 $\mathrm{cm}$ long and inoculated into petri dishes containing basal MS (Murashige \& Skoog, 1962) media with $30 \mathrm{gL}^{-1}$ sucrose and $3 \mathrm{gL}^{-1}$ gelrite at $\mathrm{pH}$ 5.8. The experiment was repeated six times with one replicate for each treatment whereby there was three explants per replicate. The explants were placed in constant temperature of $25 \pm 2^{\circ} \mathrm{C}$ under continuous illumination of cool white fluorescent lamps at light intensity of $32.5 \mu \mathrm{mol} \mathrm{m} \mathrm{m}^{-2} \mathrm{~s}^{-1}$ in the culture room. The numbers of axenic, contaminated, and necrotic explants were recorded two weeks later. The axenic explants obtained were maintained in glass bottles containing $40 \mathrm{ml}$ of basal MS media with $30 \mathrm{gL}^{-1}$ sucrose and $3 \mathrm{gL}^{-1}$ gelrite at $\mathrm{pH} 5.8$ and incubated in culture room regulated at constant temperature of $25 \pm 2^{\circ} \mathrm{C}$ under continuous illumination of cool white fluorescent lamps at light intensity of $32.5 \mu \mathrm{mol}$ $\mathrm{m}^{-2} \mathrm{~s}^{-1}$. The same procedure was repeated to study the effect of different concentrations of Clorox $^{\circledR}(15,20,25$, and $30 \%)$, which contained $5.25 \%$ of sodium hypochlorite with different durations $(15,20,25$, and $30 \mathrm{mins})$ on the number of axenic, contaminated and necrotic explants.

\section{Callus Induction and Biomass Yield}

The leaves of in vitro plantlets were aseptically excised into $1 \mathrm{~cm} \times 1 \mathrm{~cm}$ in size and inoculated into petri dishes containing basal MS medium supplemented with various concentrations of 2,4-Dichlorophenoxyacetic (2,4-D) $(0,0.1,0.3$, $0.5,0.7,1.0,1.5$, and $2.0 \mathrm{mg} / \mathrm{L})$ or picloram $(0$, $0.5,1.0,2.0$, and $4.0 \mathrm{mg} / \mathrm{L}), 30 \mathrm{gL}^{-1}$ sucrose and $3 \mathrm{gL}^{-1}$ gelrite. The $\mathrm{pH}$ of the medium was adjusted to 5.8 with a few drops of $\mathrm{HCl}$ or $\mathrm{KOH}$ before sterilized with autoclave at $121^{\circ} \mathrm{C}$ for 15 minutes under $1.05 \mathrm{~kg} \mathrm{~cm}^{-2}$ pressure. There were a total of five replicates with three explants per replicate for each concentration. The cultures were incubated in dark condition for 24 hours in the culture room maintained at $25 \pm$ $2^{\circ} \mathrm{C}$. The formation of callus was observed every week for a duration of eight weeks. The number of explants forming calli, the morphology and colour of the callus were recorded. Callus induction frequency was determined according to Javed et al. (2012).

$$
\begin{gathered}
\text { Callus induction frequency }(C I F), \%= \\
\frac{\text { Number of explants induced callus }}{\text { Total number of explants inoculated }} \times 100
\end{gathered}
$$

In order to determine the callus biomass yield, calli were cultured on the same callus induction media with an initial inoculum size of $0.5 \mathrm{~g}$. For each concentration, five replicates were harvested after one month. The fresh weight and dried weight of the proliferated calli were recorded and the growth index of calli 
were determined. The growth index of calli was calculated according to Godoy-Hernández and Vázquez-Flota (2006).

\section{Growth index $=$ \\ Final fresh weight (g)-Initial fresh weight (g) Initial fresh weight $(g)$}

\section{Statistical Analysis}

The experiment was carried out using randomized complete block design (RCBD). The repetitions of six times for surface sterilization was carried at a different day, hence, the experiment was blocked by day. The induction of calli on media supplemented with different auxins was carried out on different day, therefore, the experiment was blocked by day. The data were analyzed using Two-way ANOVA and the mean values were compared using Tukey's test at $\mathrm{p} \leq 0.05$ with the aid of IBM $^{\circledR}$ SPSS $^{\circledR}$ Statistics 22.

\section{RESULTS AND DISCUSSION}

\section{Surface Sterilization}

Explants were subjected to various concentrations of mercuric chloride and Clorox ${ }^{\circledR}$ for different durations. Explants with no sign of fungal and bacterial contaminations were regarded as axenic explants after incubation in basal MS medium for two weeks. The results indicated that there was significant difference in the number of axenic explants treated with different concentrations of mercuric chloride for various durations (Table 1). Treatment $C$ with mean number of axenic explants of $1.3 \pm 0.3$ was significantly higher than treatment $\mathrm{D}$ with no axenic explants obtained. However, the mean number of axenic explants under treatment $\mathrm{C}(1.3 \pm 0.3)$ was comparable with treatment $\mathrm{A}, \mathrm{B}, \mathrm{E}, \mathrm{F}, \mathrm{G}, \mathrm{H}$, and I with the mean values ranged from $0.3 \pm 0.2$ to $1.0 \pm 0.5$. Nonetheless, all the axenic explants obtained were undergone necrosis after subcultured into new basal MS media where the leaves eventually turns yellow and became brown (Figure 1) which lead to stunted growth and no further sign of survival. The mean number of contaminated explants for treatment A $(2.5 \pm 0.2)$ and treatment $\mathrm{D}(2.7 \pm 0.2)$ were comparable to each other but significantly higher than treatment I with mean values of 0.8 \pm 0.3 . However, treatment $\mathrm{A}$ and treatment $\mathrm{D}$ has mean number of contaminated explants that were comparable to treatments $\mathrm{B}, \mathrm{C}, \mathrm{E}, \mathrm{F}, \mathrm{G}$, and $\mathrm{H}$ with mean number ranged from $1.3 \pm 0.5$ to $1.8 \pm 0.4$. The mean numbers of necrotic explants were not significantly difference among different treatments. Mercuric chloride was used as disinfectant to remove surface microorganisms as high concentration of mercuric chloride with increasing durations efficiently inhibited the growth of bacteria (Das et al., 2012). However, it was seldom used as sterilizing agent due to the danger of usage and difficulty of disposal (Akin-Idowu et al., 2009).

Table 1. The mean number of axenic, contaminated and necrotic explants obtained after treated with various concentrations of mercuric chloride for different durations.

\begin{tabular}{cccccc}
\hline \multirow{2}{*}{ Treatment } & $\begin{array}{c}\text { Concentration of } \\
\text { mercuric chloride }\end{array}$ & $\begin{array}{c}\text { Time } \\
\text { duration }\end{array}$ & \multicolumn{2}{c}{ Mean number of explant \pm S.E. } \\
\cline { 4 - 6 } & $(\boldsymbol{\%})$ & 1 & $0.3 \pm 0.2 \mathrm{ab}$ & $2.5 \pm 0.2 \mathrm{a}$ & $0.2 \pm 0.2 \mathrm{a}$ \\
\hline $\mathrm{A}$ & 0.1 & 3 & $1.0 \pm 0.4 \mathrm{ab}$ & $1.8 \pm 0.4 \mathrm{ab}$ & $0.2 \pm 0.2 \mathrm{a}$ \\
$\mathrm{B}$ & 0.1 & 6 & $1.3 \pm 0.3 \mathrm{a}$ & $1.5 \pm 0.2 \mathrm{ab}$ & $0.2 \pm 0.2 \mathrm{a}$ \\
$\mathrm{C}$ & 0.1 & 1 & $0 \mathrm{~b}$ & $2.7 \pm 0.2 \mathrm{a}$ & $0.3 \pm 0.2 \mathrm{a}$ \\
$\mathrm{D}$ & 0.2 & 3 & $1.0 \pm 0.5 \mathrm{ab}$ & $1.3 \pm 0.5 \mathrm{ab}$ & $0.7 \pm 0.3 \mathrm{a}$ \\
$\mathrm{E}$ & 0.2 & 6 & $0.5 \pm 0.2 \mathrm{ab}$ & $1.7 \pm 0.4 \mathrm{ab}$ & $0.8 \pm 0.5 \mathrm{a}$ \\
$\mathrm{F}$ & 0.2 & 1 & $0.3 \pm 0.2 \mathrm{ab}$ & $1.8 \pm 0.3 \mathrm{ab}$ & $0.8 \pm 0.4 \mathrm{a}$ \\
$\mathrm{G}$ & 0.5 & 3 & $0.8 \pm 0.4 \mathrm{ab}$ & $1.8 \pm 0.4 \mathrm{ab}$ & $0.3 \pm 0.3 \mathrm{a}$ \\
$\mathrm{H}$ & 0.5 & 6 & $0.8 \pm 0.3 \mathrm{ab}$ & $0.8 \pm 0.3 \mathrm{~b}$ & $1.3 \pm 0.4 \mathrm{a}$ \\
\hline $\mathrm{I}$ & 0.5 & 6 &
\end{tabular}

Mean values of the same column for each treatment followed by the different letters were significantly different (Tukey's test, $\mathrm{p} \leq 0.05$ ).

Note: Letters of ' $a$ ' and ' $b$ ' indicate there were significant difference in terms of number of explant if the values from the same column had different letters. 


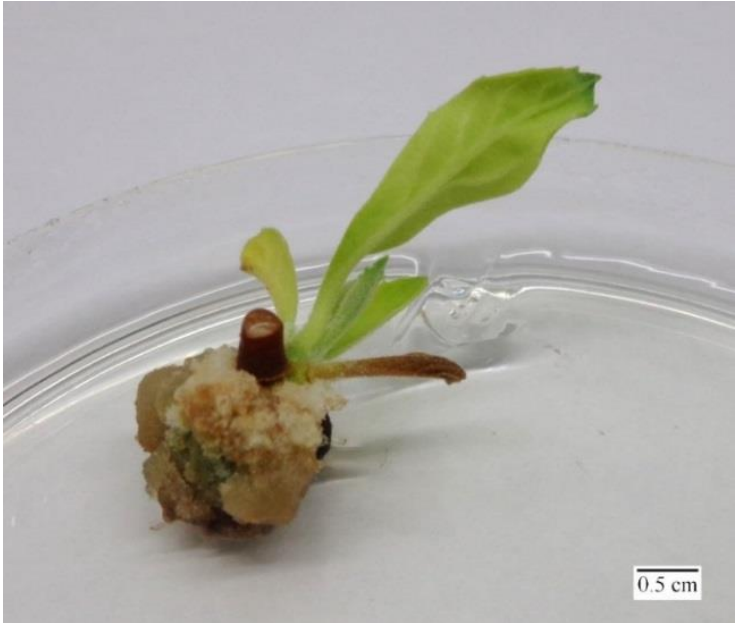

Figure 1. The leaves of the axenic explants turning yellow and eventually brown after treatment with mercuric chloride.

The observation of necrosis and consequent death of explants after surface sterilized with mercuric chloride was probably due to phytotoxicity of mercuric chloride (Babaei et al., 2013). Table 2 depicted the effect of various concentrations of Clorox $^{\circledR}$ with different durations on surface sterilization of $V$. amygdalina. There were no significance effects of different concentrations of Clorox $^{\circledR}$ for different durations on the mean number of axenic, contaminated and necrotic explants recorded in the present study. However, the mean number of axenic explants was ranged from $0.8 \pm 0.4$ to $2.3 \pm 0.3$ and the axenic explants were survived by developing healthy green leaves and numerous roots after subcultured into new basal MS media. Sodium hypochlorite which was the active ingredient in Clorox $^{\circledR}$, was one of the most commonly used disinfectant (Beyl \& Trigiano, 2014). As there was no significant difference in the number of axenic explants among different treatments of Clorox $^{\circledR}$, treatment 1 (15\% of Clorox $^{\circledR}, 15$ mins) was recommended instead of mercuric chloride due to the survival of healthy explant after subcultured.

\section{Callus Induction and Biomass Yield}

Induction of callus was experimented by inoculating in vitro leaf explants in MS media supplemented with various concentrations of 2,4-D and picloram (Table 3). There was no observation of callus formation in the leaf explants cultured in MS medium only. Hence, the CIF value of treatment 1 was significantly lowest. The CIF values for treatments $2,3,4,5$, $6,7,8,9,10,11$, and 12 which was ranged from $73.3 \pm 19.4$ to $100.0 \pm 0.0 \%$ were comparable to each other. All the leaf explants under treatments 2, 3, 5, 6, 7, 8, 9, and 10 showed fully formation of calli as their CIF values were $100.0 \pm 0.0 \%$. However, root formation was observed in the leaf explants cultured in MS media supplemented with lower concentrations

Table 2. The mean number of axenic, contaminated and necrotic explants obtained after treated with various concentrations of Clorox ${ }^{\circledR}$ for different durations.

\begin{tabular}{cccccc}
\hline \multirow{2}{*}{ Treatment } & $\begin{array}{c}\text { Concentration } \\
\text { of Clorox }{ }^{\circledR}(\boldsymbol{\%})\end{array}$ & $\begin{array}{c}\text { Time duration } \\
(\mathbf{m i n})\end{array}$ & \multicolumn{2}{c}{ Mean number of explant \pm S.E. } \\
\cline { 3 - 5 } & 15 & 15 & $1.8 \pm 0.5 \mathrm{a}$ & $1.2 \pm 0.5 \mathrm{a}$ & Contaminated \\
\hline $\mathrm{a}$ & 15 & 20 & $2.3 \pm 0.3 \mathrm{a}$ & $0.7 \pm 0.3 \mathrm{a}$ & $0 \mathrm{a}$ \\
$\mathrm{b}$ & 15 & 25 & $2.0 \pm 0.4 \mathrm{a}$ & $0.7 \pm 0.3 \mathrm{a}$ & $0.3 \pm 0.2 \mathrm{a}$ \\
$\mathrm{c}$ & 15 & 30 & $1.3 \pm 0.5 \mathrm{a}$ & $1.5 \pm 0.5 \mathrm{a}$ & $0.2 \pm 0.2 \mathrm{a}$ \\
$\mathrm{d}$ & 20 & 15 & $1.5 \pm 0.6 \mathrm{a}$ & $1.2 \pm 0.5 \mathrm{a}$ & $0.3 \pm 0.3 \mathrm{a}$ \\
$\mathrm{e}$ & 20 & 20 & $1.5 \pm 0.6 \mathrm{a}$ & $1.2 \pm 0.4 \mathrm{a}$ & $0.3 \pm 0.2 \mathrm{a}$ \\
$\mathrm{f}$ & 20 & 25 & $1.8 \pm 0.3 \mathrm{a}$ & $0.8 \pm 0.3 \mathrm{a}$ & $0.2 \pm 0.2 \mathrm{a}$ \\
$\mathrm{g}$ & 20 & 30 & $1.5 \pm 0.6 \mathrm{a}$ & $0.8 \pm 0.5 \mathrm{a}$ & $0.7 \pm 0.5 \mathrm{a}$ \\
$\mathrm{h}$ & 25 & 15 & $2.0 \pm 0.0 \mathrm{a}$ & $1.0 \pm 0.0 \mathrm{a}$ & $0 \mathrm{a}$ \\
$\mathrm{i}$ & 25 & 20 & $1.8 \pm 0.4 \mathrm{a}$ & $1.0 \pm 0.4 \mathrm{a}$ & $0 \mathrm{a}$ \\
$\mathrm{j}$ & 25 & 25 & $2.3 \pm 0.2 \mathrm{a}$ & $0.7 \pm 0.2 \mathrm{a}$ & $0 \mathrm{a}$ \\
$\mathrm{k}$ & 25 & 30 & $1.8 \pm 0.5 \mathrm{a}$ & $0.7 \pm 0.3 \mathrm{a}$ & $0.3 \pm 0.2 \mathrm{a}$ \\
$\mathrm{l}$ & 30 & 15 & $2.0 \pm 0.5 \mathrm{a}$ & $0.8 \pm 0.5 \mathrm{a}$ & $0.2 \pm 0.2 \mathrm{a}$ \\
$\mathrm{m}$ & 30 & 20 & $1.8 \pm 0.6 \mathrm{a}$ & $1.2 \pm 0.6 \mathrm{a}$ & $0 \mathrm{a}$ \\
$\mathrm{n}$ & 30 & 25 & $2.0 \pm 0.5 \mathrm{a}$ & $1.0 \pm 0.5 \mathrm{a}$ & $0 \mathrm{a}$ \\
$\mathrm{o}$ & 30 & 30 & $0.8 \pm 0.4 \mathrm{a}$ & $2.0 \pm 0.5 \mathrm{a}$ & $0.2 \pm 0.2 \mathrm{a}$ \\
\hline
\end{tabular}

Means within the same column for each treatment followed by the same letter were not significantly different (Tukey's test, $\mathrm{p} \leq 0.05$ ).

Note: Letter ' $a$ ' indicates there was no significant difference in terms of number of explant if the values from the same column had the same letter. 
of 2,4-D as depicted in Figure 2. The calli induced from leaf explants can be observed in Figure 3 where the calli formed were friable and light brown in colour while there was discolouration in the leaf explants. The same concentrations of 2,4-D and picloram used to induce calli were applied to determine the best treatment for callus biomass yield. As there was no callus produced in leaf explants cultured in MS media only, treatment 1 was not included for determining the best treatment for callus biomass yield. Growth index and dried weight of calli were used as parameters to determine the best concentration of auxin for biomass production. However, the values of both growth index and dried weight of calli obtained for all treatments were not significantly difference from each other. The growth index for treatments 2 to 12 was ranged from $2.2 \pm 0.0$ to $5.2 \pm 0.9$ while the dried weight of calli was ranged from $80.0 \pm 25.4$ to $188.2 \pm 26.2 \mathrm{mg}$. The calli proliferated under treatments 2 to 12 was friable and light brown in colour as shown in Figure 4. Plant growth regulator was indispensable for plant tissue induction, growth and organ differentiation (Zhou \& Liu, 2009). Auxins and cytokinins were the most crucial for morphogenesis and regulating growth in plant

Table 3. Inoculation of in vitro leaf explants into basal MS media supplemented with different concentrations of 2,4-D and picloram for callus induction and biomass production.

\begin{tabular}{ccccccc}
\hline Treatment & $\begin{array}{c}\text { Concentration } \\
\text { of 2,4-D } \\
(\mathbf{m g} / \mathbf{L})\end{array}$ & $\begin{array}{c}\text { Concentration } \\
\text { of picloram } \\
(\mathbf{m g} / \mathbf{L})\end{array}$ & $\begin{array}{c}\text { CIF }(\%) \text { at } \\
\text { week 8 }\end{array}$ & $\begin{array}{c}\text { Callus morphology } \\
\begin{array}{c}\text { Growth } \\
\text { index }\end{array}\end{array}$ & $\begin{array}{c}\text { Dried weight } \\
(\mathbf{m g})\end{array}$ \\
\hline 1 & 0.0 & 0.0 & $0.0 \mathrm{~b}$ & No callus formed & - & - \\
2 & 0.1 & 0.0 & $100.0 \pm 0.0 \mathrm{a}$ & Friable, light brown & $2.8 \pm 0.5 \mathrm{a}$ & $125.8 \pm 14.6 \mathrm{a}$ \\
3 & 0.3 & 0.0 & $100.0 \pm 0.0 \mathrm{a}$ & Friable, light brown & $2.5 \pm 0.2 \mathrm{a}$ & $111.2 \pm 9.5 \mathrm{a}$ \\
4 & 0.5 & 0.0 & $93.3 \pm 6.7 \mathrm{a}$ & Friable, light brown & $2.6 \pm 0.2 \mathrm{a}$ & $86.6 \pm 25.0 \mathrm{a}$ \\
5 & 0.7 & 0.0 & $100.0 \pm 0.0 \mathrm{a}$ & Friable, light brown & $2.6 \pm 0.3 \mathrm{a}$ & $110.8 \pm 9.2 \mathrm{a}$ \\
6 & 1.0 & 0.0 & $100.0 \pm 0.0 \mathrm{a}$ & Friable, light brown & $2.3 \pm 0.1 \mathrm{a}$ & $83.8 \pm 24.0 \mathrm{a}$ \\
7 & 1.5 & 0.0 & $100.0 \pm 0.0 \mathrm{a}$ & Friable, light brown & $2.2 \pm 0.0 \mathrm{a}$ & $100.0 \pm 2.2 \mathrm{a}$ \\
8 & 2.0 & 0.0 & $100.0 \pm 0.0 \mathrm{a}$ & Friable, light brown & $2.3 \pm 0.4 \mathrm{a}$ & $80.0 \pm 25.4 \mathrm{a}$ \\
9 & 0.0 & 0.5 & $100.0 \pm 0.0 \mathrm{a}$ & Friable, light brown & $5.2 \pm 0.9 \mathrm{a}$ & $188.2 \pm 26.2 \mathrm{a}$ \\
10 & 0.0 & 1.0 & $100.0 \pm 0.0 \mathrm{a}$ & Friable, light brown & $4.4 \pm 1.3 \mathrm{a}$ & $166.6 \pm 37.2 \mathrm{a}$ \\
11 & 0.0 & 2.0 & $73.3 \pm 19.4 \mathrm{a}$ & Friable, light brown & $3.6 \pm 0.9 \mathrm{a}$ & $143.8 \pm 29.6 \mathrm{a}$ \\
12 & 0.0 & 4.0 & $83.3 \pm 9.6 \mathrm{a}$ & Friable, light brown & $3.2 \pm 0.8 \mathrm{a}$ & $132.2 \pm 23.4 \mathrm{a}$ \\
\hline
\end{tabular}

Mean values within the same column for each concentration followed by the same alphabet were not significantly different (Tukey's test, $\mathrm{p} \leq 0.05$ ).

Note: Letters of ' $a$ ' and ' $b$ ' indicate there were no significant difference in terms of number of explant if the values from the same column had the same letter.

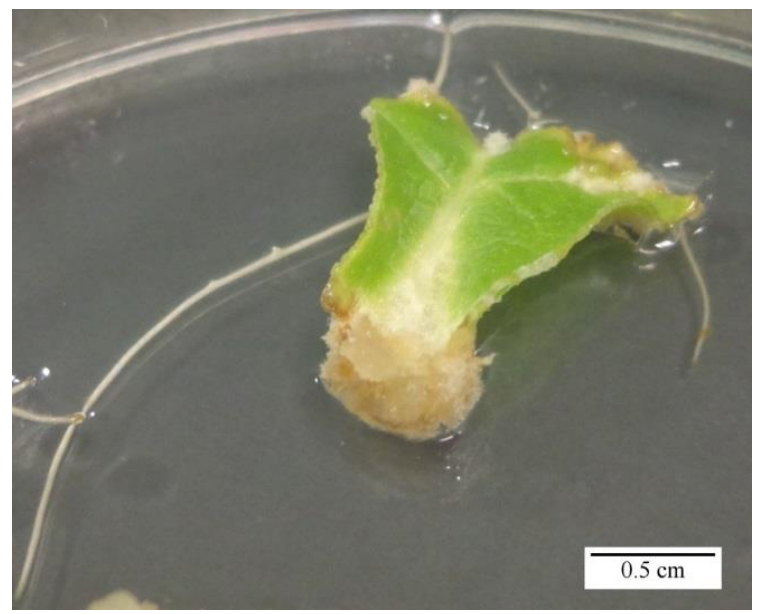

Figure 2. The development of roots were observed in the leaf explants inoculated in basal MS media supplemented with 0.1 and $0.3 \mathrm{mg} / \mathrm{L}$ of 2,4-D.

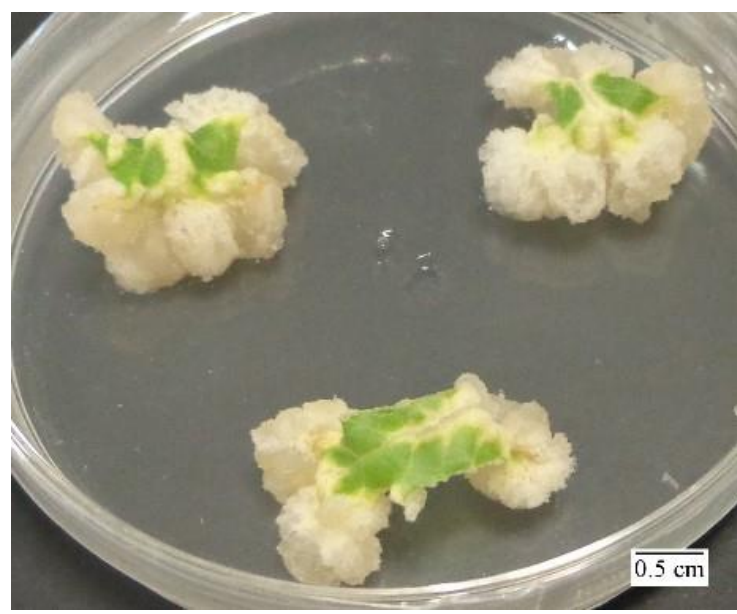

Figure 3. Development of calli at the wounded area of leaf explants inoculated in basal MS medium with 0.5 $\mathrm{mg} / \mathrm{L}$ of 2,4-D after 8 weeks. 


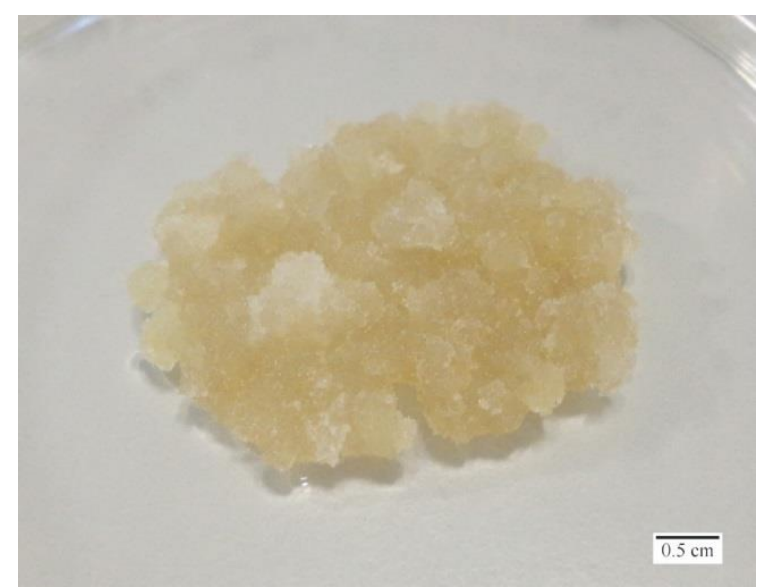

Figure 4. Proliferation of calli in basal MS medium supplemented with $0.1 \mathrm{mg} / \mathrm{L}$ 2,4-D from an initial inoculum size of $0.5 \mathrm{~g}$. The calli were friable and light brown in colour.

tissue and organ cultures (George et al., 2007). This explained for the reason of no callus formation in leaf explants cultured in MS media only. In plant tissue culture, changes in auxin concentrations could change the type of growth that was, from stimulation of root formation to callus induction (George et al., 2007). Hence, leaf explants cultured in MS media supplemented with low concentrations of 2,4-D resulted in roots formation. As there was no significant difference in CIF values between 2,4-D and picloram, MS media supplemented with $0.5 \mathrm{mg} / \mathrm{L} 2,4-\mathrm{D}$ or $0.5 \mathrm{mg} / \mathrm{L}$ picloram was recommended for callus induction while MS media with $0.1 \mathrm{mg} / \mathrm{L} \quad 2,4-\mathrm{D}$ or $0.5 \mathrm{mg} / \mathrm{L}$ picloram was recommended for callus proliferation and biomass production.

\section{CONCLUSION}

In conclusion, Clorox ${ }^{\circledR}$ was recommended to be used as disinfectant for $V$. amygdalina instead of mercuric chloride due to its phytotoxicity. It was recommended to surface sterilized with $15 \%$ of Clorox $^{\circledR}$ for 15 minutes. Both 2,4-D and picloram were suitable for callus induction and biomass production.

\section{ACKNOWLEDGEMENTS}

The authors are thankful to MyBrainSc under Ministry of Higher Education Malaysia for the financial support and to Universiti Malaysia Sarawak for the laboratory facilities.

\section{REFERENCES}

Akin-Idowu, P.E., Ibitoye, D. O., \& Ademoyegun, O.T. (2009). Tissue culture as a plant production technique for horticultural crops. African Journal of Biotechnology, 8(16): 3782-3788.

Audu, S.A., Taiwo, A.E., Ojuolape, A.R., Sani, A.S., Bukola, A.R., \& Mohammed, I. (2012). A study review of documented phytochemistry of Vernonia amygdalina (Family Asteraceae) as the basis for pharmacologic activity of plant extract. Journal of Natural Sciences Research, 2(7): 1-9.

Babaei, N., Abdullah, N.A.P., Saleh, G., \& Abdullah, T.L. (2013). Control of contamination and explant browning in Curculigo latifolia in vitro cultures. Journal of Medicinal Plants Research, 7(8): 448-454.

Beyl, C.A. \& Trigiano, R.N. (2014). Plant propagation concepts and laboratory exercises. Second Edition. London: CRC Press. P 383.

Das, M.P., Rebecca, L.J., Sharmila, S., \& Chatterjee, S. (2012). Study on the effect of mercury (II) chloride as disinfectant on mixed culture. Journal of Chemical and Pharmaceutical Research, 4(12): 4975-4978.

Fomum, F.U. (2004). Vernonia amygdalina Delile. In: Grubben, G.J.H. \& Denton, O.A. (Eds.). Vegetables. Wageningen: PROTA Foundation. Pp 543-546.

George, E.F., Hall, M.A., \& Klerk, G.D. (2007) Plant propagation by tissue culture $3^{\text {rd }}$ Edition: Volume 1. The background. Springer Science \& Business Media. Pp 174 and Pp 185.

Godoy-Hernández, G. \& Vázquez-Flota, F.A. (2006). Growth measurements: Estimation of cell division and cell expansion. In: Loyola-Vargas, V.M. \& Vázquez-Flota, F. (Eds). Plant cell culture protocols. New Jersey: Humana Press Inc. Pp 51-58.

Hu, G. \& Jia, J. (2012). Production of useful secondary metabolites through regulation of biosynthetic pathway in cell and tissue suspension culture of medicinal plants. In: Leva, A. \& Rinaldi, L.M.R. (Eds.). Recent advances in plant in vitro culture. USA: Intech. Pp 197-210.

Javed, B., Farhatullah, Shah, S.H., \& Ali, I. (2012). In vitro analysis of callus induction in interspecifically hybridized F4-5 populations of Brassica. Pakistan Journal of Botany, 44(2): 787790. 
Khalafalla, M.M., Elgaali, E.I., \& Ahmed, M.M. (2007). In vitro multiple shoot regeneration from nodal explants of Vernonia amygdalina - An important medicinal plant. In: Ahmed, K. Z. (Ed.). $8^{\text {th }}$ African Crop Science Conference Proceedings. El-Minia, 27-31 October 2007. Egypt: African Crop Science Society. Pp 747752.

Linden, J.C. (2002). Secondary products from plant tissue culture. In: Doelle, H.W., Rokem, S., \& Berovic, M. (Eds.). Biotechnology, Vol. VI. France: UNESCO-EOLSS. Pp 53-74.

Murashige, T. \& Skoog, F. (1962). A revised medium for rapid growth and bioassay with tobacco tissue culture. Physiologia Plantarum, 15: 473-497.

Ofori, D.A., Anjarwalla, P., Jamnadass, R., Stevenson, P.C., \& Smith, P. (2013). Vernonia amygdalina Del. Academics Development Practitioners Extension Policy Makers Scientists. Nairobi, Kenya: World Agroforestry Centre (ICRAF).
Ramakrishna, A. \& Ravishankar, G.A. (2011). Influence of abiotic stress signals on secondary metabolites in plants. Plant Signaling \& Behavior, 6(11): 1720-1731.

Rao, S.R. \& Ravishankar, G.A. (2002). Plant cell cultures: Chemical factories of secondary metabolites. Biotechnology Advances, 20: 101153.

Toyang, N.J. \& Verpoorte, R. (2013). A review of the medicinal potentials of plants of the genus Vernonia (Asteraceae). Journal of Ethnopharmacology, 146(3): 681-723.

Yeap, S.W., Ho, W.Y., Beh, B.K., Liang, W.S., Ky, H., Yousr, A.H.N., \& Alitheen, N.B. (2010). Vernonia amygdalina, an ethnoveterinary and ethnomedical used green vegetables with multiple bio-activites. Journal of Medicinal Plants Research, 4(25): 2787-2812.

Zhou, R.J. \& Liu, M.J. (2009). Effect of plant growth regulators on tissue culture in Chinese jujube. Acta Horticulturae, 840: 309-314. 